\title{
Demographic Trends in Estonia Throughout the Centuries
}

\author{
KALEV KATUS \\ Estonia Interuniversitary \\ Population Research Centre
}

\section{Introduction}

The end of the 20th century seems to be composed of rapid changes all over the world. The extent of the political events of 1987-1989 in Estonia can be compared to the changes of a couple of "normal» decades. Several aspects of social life are rapidly changing. Against this dynamic background the inertia of demographic development catches the eye. Not a week, a month nor a year serves as a time unit, instead a remarkably longer time inteval is needed: a generation.

As to the number and acuteness of the demographic problems, the present situation in Estonia could be considered rather colorful. How several problems are perceived, as well as attitudes and probably the application of possible ways of regulation, depend to a great extent on the balance of social forces. But in view of the causal interpretation of the demographic situation, the political and ideological processes should be left aside and the regularities of the demographic development should be focused on.

This short review of Estonian demographic history elucidates that the Estonian population may be characterized by all the same general demographic tendencies which have occurred in other nations as well. In most cases the modern demographic situation cannot be understood only by looking at post-war processes. The events that have taken place 3-5 generations ago, partly even earlier, will have great importance now and even in the future. By viewing the present situation as the result of a continuous demographic development, some of the "strange" phenomena may seem normal. Or vice versa: some of the ordinary phenomena turn out to be strange. After all, to clarify the demogaphic situation at any moment one should also glance at the past. Considering future perspectives, knowledge about a longer historical period becomes even more necessary.

\section{The time of traditional reproduction}

The first reliable demographic data are confined to the size of the population. The earliest of them dates back to the beginning of a ancient fight for freedom, to about the year 1200 . We know about the military potential of the Estonians from Henry of Latvia's chronicle. "Liber Census Daniae» tells also about the area under cultivation, which was 21,000 plowland. This arable land managed to feed 100,000 $-200,000$ people, depending on the yields and the annual average food consumption per capita. Johansen (1925), Moora (1961), Tarvel (1970), Palli (1973) and some, other historians have had a somewhat different approach when estimating the size of the population. As fishing, hunting and gathering mushrooms and berries served 
as additional sources of food for the people of that period, a somewhat higher number may be considered more probable. The facts known about the fight for freedom also speak on behalf of a larger Estonian population. After defeating the Livonians and the Latvians the Order of the Sword was not able to conquer Estonia. After a ten-year fight they turned to Denmark and Sweden asking for help. The troops led by King Voldemar II invaded the north of Estonia. At the same time the Swedes attacked Estonia from the west.

Later estimates of the size of the Estonian population using additional information seem to point to a higher level than the earlier ones. A population of 200,000 during this period could be considered rather large. In almost the same period the Swedish population has been estimated at 400,000, the Norwegians at 200,000, the Danes at 340,000-500,000, the Lithuanians at 120,000-170,000 and the population of Finland at approximately half of the Estonian population. Presumably, the relatively great number of the Estonians and the high population density is related to the east-west trading routes in Estonia. This would later prove fatal for the Estonians.

After Peter the Great had broken open a window into Europe through the Estonian territory, the number of Estonians has been estimated to be 150,000 (1712). From the 1200 s to the 1700 s the size of the population declined rather than grew, particularly if at least two considerable foreign inmigration flows and their gradual assimilation are taken into account.

Undoubtedly, the number of the Estonian population did not remain stable during these 500 years. The years of population growth alternated with periods of crisis, when the number of deaths exceeded the number of births. The main reasons for the population crises were famines, epidemics and wars. In Estonia the influence of the wars must be especially underlined. The ancient fight for freedom is regarded as the first important period of population crisis. The second one was the period after the Jüriöö uprising, when Harjumaa (probably the major part of northern Estonia) was desolated, as told in Hoeneke's chronicle. Historians have not found enough sources to provide numerical estimates. The next and one of the severest population crises accompanied the Livonian War. In 1550, before the war, the Estonian population numbered $240,000-280,000$. Only $70,000-100,000$ were left in 1620 1625. The population was quickly restored and reached about $350,000-400,000$ at the end of the 17 th century. The Great Famine, the Northern War and the last plague again reduced the size of population to 150,000 in 1712 .

During that period population changes were characteristic for all nations. In other European countries however, the population as a whole grew 1.5-2-fold. As a consequence of its more numerous population crises Estonia was in worse condition than in average. Since the 13th century the geopolitical location between the east and the west was the reason for zero population growth. Some neighboring nations were eren in worse condition: the number of Livonians, Prussians and probably Votians and Vepsians was remarkably reduced during the same period.

Reproduction in Estonia within the framework of the traditional pattern has been most thoroughly studied by Palli $(1973 ; 1980 ; 1988)$. His studies leave no doubt the fact that reproduction in Estonia was analogous with that in other countries. Fertility was rather high: $4-5$ children per woman. During the normal years about $2.5-3$ of the children reached maturity. This number was considerably smaller during the years of crisis. The mean length of life at birth fluctuated between 25 to 35 years. Because of the numerous local crises, when the mortality of children and the elderly was greatly affected, the usual high share of those in reproductive age became even more prominent. Therefore, the generations alternated rapidly and the population 
recovered rather quickly from the losses during the years of crisis.

Already at the beginning of the 18th century the first symptoms of the end of traditional reproduction emerged in Estonia. The spread of the European marriage pattern was one symptom: the average age at marriage was over 23 years and the proportion of married women less than 55 percent (Hajnal 1965). The European marriage pattern was typical west of the Leningrad-Triest line. In Otepää parish the average age at first marriage for females was 21.5 years in $1725-1749,22.8$ years in $1750-1774$ and 24.2 years in $1775-1799$ (Palli 1988, 87). In 1765 the proportion of married women was 55.8 percent of the adult population of Otepää (Palli 1988, 112). Hence, the European marriage pattern took shape in Estonia at the end of the 18 th century.

The European marriage pattern was one of the heralds declaring the beginning of the decay of the traditional population reproduction that had lasted for hundreds of years. The spread of the European marriage pattern resulted in a clear distinction in the demographic development between Estonia and its closest eastern neighbor, as well as the majority of the Eastern European countries. Being politically an eastern outpost in the west (Estonia was conquered by Peter the Great in 1710), it now became demographically the western outpost in the east. The non-synchronity of its demographic development with that of Russia became apparent about 200 years ago. But this is a factor of great importance for the demographic situation in present day Estonia. This non-synchronity is also a key to understanding future development.

Because of the changes in the east-west trading routes and the annexing of Estonia to the Russian Empire, direct warfare on Estonian territory was avoided for a period of 200 years. Hence, the main factor for population crises disappeared. Likewise, other factors - epidemics and famine - graphically lost their importance as in most advanced European countries. Mortality remained on the "normal» level, typical to the traditional reproduction pattern. Because of the spread of the European marriage pattern, fertility decreased, though rather slowly at the beginning. Thus, pre-transitional population growth became possible. In Estonia the number of the population, which was about 150,000 after the Northern War, increased up to 730,000 in 1850 (Katus 1982, 103). The growth of the population up to almost fivefold partly as a result of immigration - in less than 150 years was similar to that in other countries during the same period. Compared to its neighbors, Estonia's growth was even bigger. Nevertheless, compared to its neighbors in the Baltic basin, the Estonians remained a little nation, which was a result of the small "pre-start» number of the population.

\section{The demographic transition}

In the middle of the last century the demographic transition began to take place in Estonia. Until now this process has been studied rather little, especially the beginning of the period. The critical turn took place in 1850-1870, conventionally seen in 1850 . The crude birth and death rates for that period showed a continuous decline with only short-period fluctuations (Figure 1).

The final phase of the demographic transition is already well provided with data such as e.g. Coale's indices and total fertility rates (Table 1). In 1930 fertility had declined under the replacement level, principally as a result of the low marital fertility. The mortality criteria marking the end of the demographic transition are however, not very clear. According to the life table for 1932-1934 the average life span in Estonia was 56.4 years, 53.1 for men and 59.6 for women. The highest indicators 
Figure 1. Dynamics of crude birth and death rates, 1782-1940.

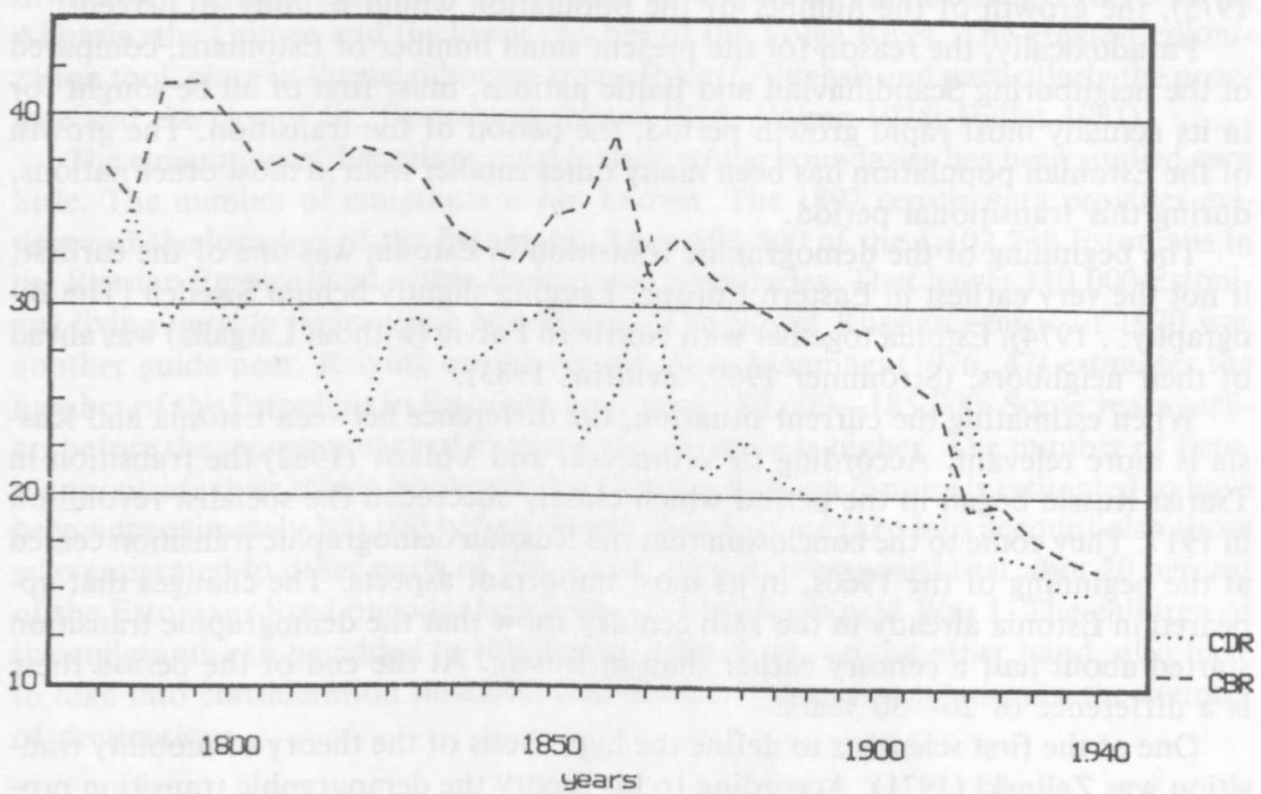

Table 1. Fertility indices of the Estonian population, census years.

$1922 / 23$

2.48

69.4

127.5

8.8

0.192
0.404
0.025
0.440
$1933 / 34$

1.88

61.0

110.2

12.0

0.153

0.289

0.030

0.476

for that period in Europe showed 62.7 years in Holland and 62.4 years in Norway. The life expectancy in Estonia was lower because of high infant mortality: in 1935 -1939 still 85.1 per one thousand. Among the causes of death endogeneous causes had already become the most important (Rahvastikuprobleeme 1937, 148). Even if the demographic transition in Estonia requires more thorough study, one may consider it to have reached its end before the Second World War.

When describing the demographic transition in Estonia we would primarily touch upon two aspects. Firstly, we may conclude that the transition followed the French type, i.e. mortality and fertility declined practically simultaneously. Therefore, the increase of the population in Estonia was only about 1.6 -fold during the period 1850-1940 (Katus 1982). If we use the territory-centered method which takes into 
account the growth of a certain territory without out-migration (Pavlik and Hampl 1975), the growth of the number of the population would be only 40 percent. $^{1}$

Paradoxically, the reason for the present small number of Estonians, compared ot the neighboring Scandinavian and Baltic nations, must first of all be sought for in its actually most rapid growth period, the period of the transition. The growth of the Estonian population has been many times smaller than in most other nations, during this transitional period.

The beginning of the demographic transition in Estonia was one of the earliest, if not the very earliest in Eastern Europe. Lagging slightly behind Sweden (The Biography. . 1974), Estonia together with Northern Latvia (without Latgalia) was ahead of their neighbors. (Strömmer 1969; Zvidrinš 1983).

When estimating the current situation, the difference between Estonia and Russia is more relevant. According to Vishnevski and Volkov (1983) the transition in Tsarist Russia began in the period which closely succeeded the socialist revolution in 1917. They come to the conclusion that the Russian demographic transition ceased at the beginning of the $1960 \mathrm{~s}$, in its most important aspects. The changes that appeared in Estonia already in the 18th century show that the demographic transition started about half a century earlier than in Russia. At the end of the period there is a difference of $20-30$ years.

One of the first scientists to define the hypothesis of the theory of mobility transition was Zelinski (1971). According to his theory the demographic transition proceeds simultaneously with the growth of population mobility, especially at the phase of high fertility decline when dependency between the generations is also weakening. On the other hand, mobility is supported by the rapid growth of the population. About $80-90$ percent of the population live in the rural areas before the start of the demographic transition, but not all of them are able to get a job there. There exist principally two directions of migration flow: to urban municipalities and emigration to other countries.

From the Middle Ages up to the middle of the 19th century, there were 12 cities in Estonia. In the first half of the 19th century the proportion of the urban population was still 5-6 percent (Palli 1977, 228). In 1897 it was 19.2 percent and in 1939 32.8 percent. During the two or three last decades of the 19th century and at the beginning of this century the present network of urban settlements, excluding IdaVirumaa, was established in Estonia. The growth of the old cities and rise of the new ones had been confirmed by the migration flow from the rural areas. It still seems that the Estonian cities were socially and economically too weakly developed ro receive the whole potential migration from its hinterland. Obviously, the foreign (German-Russian) lifestyle plays a certain role in the development of the cities.

In any case, a great proportion of the Estonian migration flow had been directed outside the ethnic boundaries. The flow had two directions. One was directed overseas, as was the rule in Europe. This emigration from Estonia did not take an organized form and included mainly the coastal inhabitants, excluding the peasants. Taagepera (1989) has estimated the number of Estonian emigrants going overseas before the First World War to have been several thousands. This is an approximate and obviously too low estimate. The major part of the Estonian migrants went to the Russian inland. In several regions the conditions for getting land were practically similar to those in the New World, but going there with the whole family was much

It must be pointed out that Pavlik had presumably determined the starting point of the demographic transition in a different way. 
simpler. The colonization of Russia took an organized form in Estonia. At the end of the 19th century, Estonian settlements sprang up in Fareastern Russia, Siberia, Abhasia, the Crimea and the lower reaches of the Volga River. The greatest colonization took place in the neighboring areas: Pskoff, Vitebsk and particularly the province and the city of St. Petersburg (Nigol 1918; Vöime 1975; Pullat 1981).

The emigration of Estonians outside their ethnic boundaries has been studied very little. The number of emigrants is not known. The 1897 census data provides evidence of the location of the Estonians. Then 891,600 of the 1,102,738 Estonians in the Russian Empire lived within their ethnic boundaries. That leaves 110,000 Estonians living outside their ethnic boundaries. The Soviet Russian census of 1920 was another guide post. Relying on the census data, Maamägi $(1976,47)$ estimates the number of the Estonians in Russia to have been 180,000-185,000. Some years earlier, before the independence of Estonia, this figure was higher. The number of Estonians outside their ethnic borders but within the Russian Empire is estimated to have been approximately 200,000 before World War I. If we take into account also those who emigrated to other parts of the world, then it is supposed that abot 20 percent of the Estonians lived outside their homeland before World War I. The children of the emigrants can be added to this figure, even if we, on the other hand, also have to take into consideration possible assimilation with the population in the country of destination.

\section{The consequences caused by the Second World War and the social rearrangements}

The First and Second World War as well as the social changes which accompanied them influenced Estonian demographic development, not so much as factors modifying the development pattern but as factors changing the size of the population and the geopolitical situation.

The exact decrease of the population during the First World War and the War of Independence is not known because of data gaps before the war. It is estimated that $1,157,800$ persons were living in the nine Estonian provinces in 1915 (boundaries according to the 1881 census), or about $1,282,200$ within the boundaries of the Republic of Estonia (Kaufmann 1967, 27). In 1920 the Estonian population was $1,059,000$ (Rahvastik... 1930, 43). The decrease was 223,200 persons. Unfortunately, this number comprises both the persons killed as well as the migrants who left the country for various reasons.

Using Kaufmann's data and available census data it is possible to estimate the number of »missing» Estonians. Calculated in this way about 4,000-5,000 Estonians were killed in the war or migrated abroad, which obviously is too small a number. Obviously the pre-war number of the Estonians and the total number of the Estonian population need to be corrected.

Immediately after the war, mortality and fertility continued to decline. The baby boom in 1921-1923 was rather trivial and fertility declined under the replacement level at the end of the 1920s. Or, it can be assumed that the demographic transition was not principally influenced by the war. Nevertheless, it could be hypothesized that to a certain extent the fertility decline was accelerated by the war.

Compared to the First World War, the Second World War and the accompanying geopolitical changes caused still greater changes in Estonian demographic development. These changes occurred already in 1939 when the Germans, the second large national minority in Estonia, began to leave. From January 1940 to December 1, 
1941 (census date) the decrease was 104,120 people. During the 15 months of the Soviet period the decrease was 99,500 people, i.e. from September 1, 1940 to December 1, 1941. This number also includes 10,157 deported persons (Laasi, 1988). The reason why almost 10 percent of the Estonian population had to leave their homes was investigated in the following three years and data published. One may estimate that at the end of the war there could have been 32,500 potential returnees among those who left Estonia during this period.

Kaufmann estimates the Estonian population to have numbered 994,300 in July 1944 , i.e. before military activities in Estonian territory began for the second time, and 910,200 at the end of those activities, in January 1945. Compared to September 1,1940 the number of the population had decreased by 207,100 persons, or 18.5 percent (Kaufmann 1967, 111-113).

Although the war had ceased in Estonian territory, social life was far from normal. The number of people killed later in the Second World War, mobilization into the Red Army, liquidation of »bushwhackers», convicts, etc., is rather unkonwn at present (Parming 1972; Taagepera 1989). Further, in March 1949 20,702 persons were deported to Siberia (Laasi 1989).

It would be complicated to treat briefly the human losses caused by the Second World War and the accompanying social changes. One way to do it would be to compare the number of Estonians before the war and in 1959 when the first data after the war became available. According to the 1959 census data 892,653 Estonians lived in Estonia and 95,963 elsewhere in the Soviet Union, making a total of 988,616. According to the 1939 census 143,589 Estonians lived in the Soviet Union (Kozlov 1982, 285 ) and 999,130 in Estonia, which totals $1,142,719$. This means a difference of 154,103 persons. According to Kaufmann $(1967,140-141)$ the natural increase in Estonia was 60,000 from 1945 to 1959 , of which about 50,000 might have been Estonians. Hence, the population would have increased from the post-war period up to the 1959 census at least by this number. ${ }^{2}$ Consequently the human losses of the war would have been 200,000 persons, i.e. 17.5 percent of the pre-war number of Estonians.

Estonia can never quantitatively recover from the losses during and after the war. In contrast to the other Soviet and Estern European nations the Estonians - and also the Latvians - suffered from the catastrophe at the final phase of the demographic transition. Fertility had fallen under the replacement level and the population grew only due to the positive age structure. Under the modern slow alternation of generations such a population decrease is incurable. According to the 1989 census data there were $1,027,267$ Estonians living in the USSR, which is 89.9 percent of the pre-war number.

The war also caused changes in the Estonian population of a totally different nature. For a short period Estonia turned into an almost pure national republic. According to the 1934 census 87.7 percent were Estonians, 8.2 percent Russians, 1.7 percent Germans and 0.7 percent Swedes. In conformity with the Molotov-Ribbentrop agreement practically all the Germans left, the last of them during the first Soviet year. According to the conventions between Germany and Sweden, the departure of the Swedes was mainly organized in 1944 . The majority of the Russians were settled in the territory of mixed inhabitation at the eastern frontier. These territories were united with the Russian SSFR in 1945. As a consequence, the Estonian territory was reduced by 56,000 persons (according to Kaufmann by the autumn of 1945).

${ }^{2}$ No data is available on the natural increase of the Estonians elsewhere in the USSR. 
81 percent of them were not Estonians (Kaufmann 1967, 114, 273). Taking into account the described changes at the end of the war, the share of the Estonians could be estimated at 97.3 percent in their new territory (Katus 1987, 15). Estonia had lost all of its native minorities.

When she became a Soviet republic, Estonia was again united with territories whose demographic development was different. Now the roles changed in terms of migration. During the second half of the 19th century and at the beginning of the present, the Russian Empire acted as a receiveer of Estonian colonizers. Now a high outmigration was characteristic for the Soviet Union. Among other countries, Estonia also became a destination for migrants. Although Estonia received a relatively small share of Soviet out-migration, it was catastrophical for little Estonia.

\section{The post-war demographic development}

\section{Immigration after the Second World War}

Interest was focused on the demographic situation in Estonia, primarily as a result of the changes in the proportions between the native and migrant population. The old problems became more acute and new contradictions emerged both in demographic as well as in social development. This is not surprising when we study the extent and especially the speed of the proportional changes. Within 45 years the share of the Estonians decreased from 97.3 percent to 61.5 percent (Table 2). Such an inflow of migrants is unknown in any other European country even with a high immigration rate.

Table 2. National composition of the Estonia population, 1945-1988.

\begin{tabular}{|c|c|c|c|c|}
\hline & Total population & Estonians & Non-Estonians & $\begin{array}{l}\text { Share of the } \\
\text { Estonians } \%\end{array}$ \\
\hline $1945^{*}$ & 854,000 & 831,000 & 23,000 & 97.3 \\
\hline 1959 & $1,196,791$ & 892,653 & 304,138 & 74.6 \\
\hline 1970 & $1,356,079$ & 925,157 & 430,922 & 68.2 \\
\hline 1979 & $1,464,476$ & 947,812 & 516,664 & 64.7 \\
\hline 1989 & $1,565,662$ & 963,281 & 602,381 & 61.5 \\
\hline
\end{tabular}

After the Second World War, Estonia was a region of destination for in-migration. Immigration from the Slavic republics into Estonia was determined by the nonsynchronous demographic transition in the other parts of the Soviet Union. The change of the geopolitical situation released it. At the beginning it also comprised the migration of administrative personnel because the social rearrangements required administrators and ideologues. The economic management became bureaucratic and an urgent need for personnel up to the smallest sub-divisions emerged. Estonia also received military personnel. Army officers frequently brought their families with them.

Having reached a status of an economically relatively highly developed country during the pre-war period and possessing an effective infrastructure Estonia turned out to be an economically advantageous region for making centralized capital investments. The wave of industrialization (north-estern Estonia, Tallinn, etc.) prepared ground for migrants to settle in Estonia. This became even easier due to the deportation of Estonians at the same time. The rapid decrease of the proportion of 
the Estonians during the first five post-war years was caused not only by the solid in-migration but also by the simultaneously organized out-migration of the native population.

At the end of the 1950s the importance of the migration of administrative personnel had ceased, the survivors of deportation returned and migration between Estonia and the other regions of the USSR gradually reached a level which could be regarded as natural between two regions with different migration potential. Gradually, in the 1960s the migration potential began to fall also in the European regions of the Russian SSFR.

\section{Later immigration waves}

The decrease in the migration potential could have started a decrease of immigration into Estonia. However, rapid growth of labor resources and extensive economic development continued in other Soviet regions for the following 15-20 years but not in Estonia. The reason was again non-synchronous demographic development. Unitary centralized economic management prevailed and Estonia could not deviate from it. In the second half of the 1960 s the economic mechanisms favoring immigration into Estonia started again to operate. The initiative originated from Estonia itself, but it was disguised.

A policy favoring migration was carried out by individual enterprises for economic reasons, not by the unitary bureaucratic administration. The in-migration flow was kept relatively high due to the enlargement of Estonia's migration hinterland.

At the same time the migration flows from the immediate neighboring areas declined rather quickly. The traditional migration hinterland - the Pskoff district - serves as an example (Table 3).

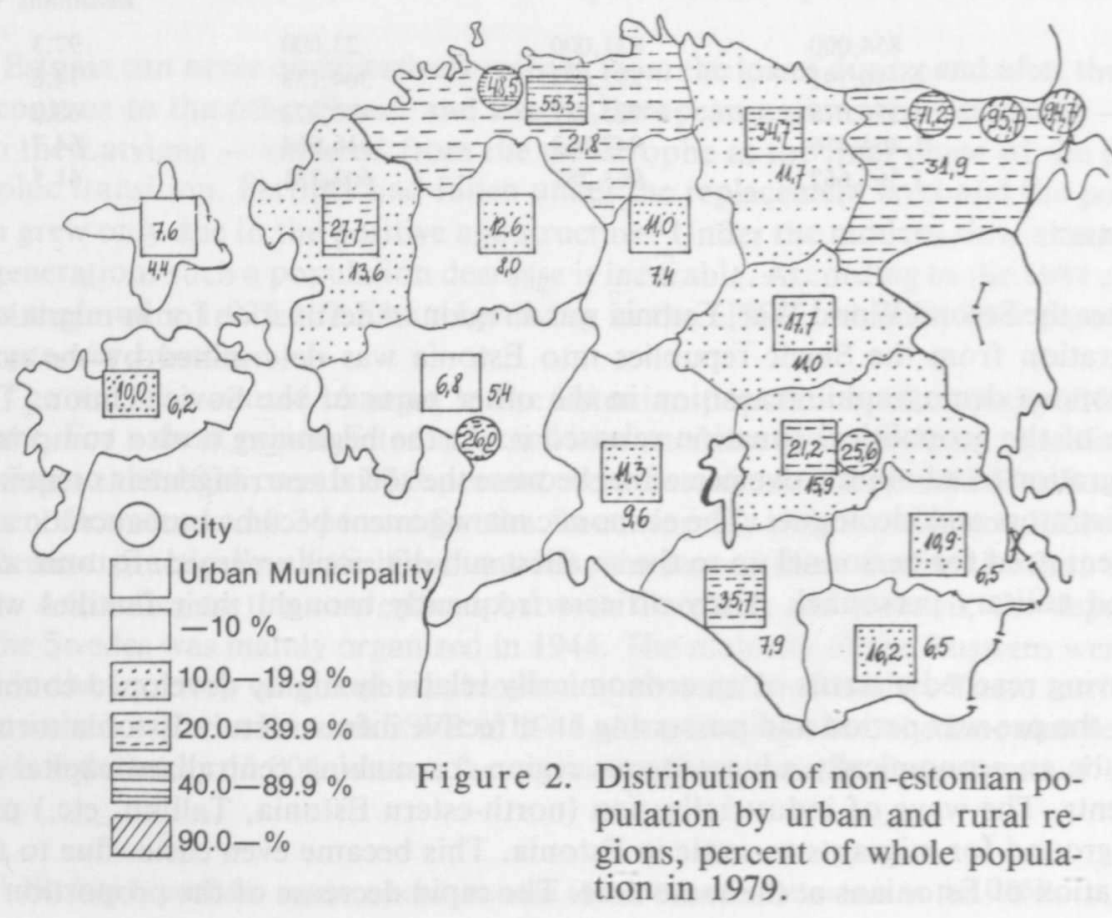


Table 3. Average annual migration flows between Estonia and the Pskoff district, 1955-1987.

$\begin{array}{lcccc}\text { Year } & \text { In-migration } & \begin{array}{c}\text { Relative change } \\ \%\end{array} & \text { Net migration } & \begin{array}{c}\text { Relative change } \\ \%\end{array} \\ 1955-59 & & 100 & & 100 \\ 1960-64 & 2,028 & 100 & +725 & 155 \\ 1965-69 & 2,030 & 75 & +1,121 & 92 \\ 1970-74 & 1,530 & 62 & +669 & 62 \\ 1975-79 & 1,249 & 49 & +448 & 50 \\ 1980-84 & 987 & 35 & +366 & 29 \\ 1985-87 & 709 & 28 & +212 & 17\end{array}$

The enlargement of Estonia's migration hinterland brought about a considerably smaller decline in in-migration and net migration than it would have been without the migration incentive policy. Anyway, not only the quantity caused trouble.

From the beginning of the 1970 s the qualitative changes became more acute. Firstly, the explosive enlargement of the migration hinterland brought into Estonia migrants with a continously changing structure. A growing share of the newcomers had no earlier contacts with Estonia and the present lifestyle seemed strange and hostile to them. But the newcomers also had little in common with the earlier migrants from Estonia's neighboring areas. Thus, the migrant population in Estonia formed a very heterogeneous society with great internal differences. The decay of the social and demographic homogenity of the Estonian population has made social development more complicated in almost every aspect.

Secondly, the migration incentive policy was based upon people's aspiration for material wealth. It was responded to primarily by those with a low sense for their native place, which means that they felt at home anywhere where better consumer conditions were available. Such a »highly-adaptive» population aspired to social unification. Estonia happened to be the region which attracted this kind of population from its whole hinterland (Katus 1989). The present chauvinist movement (for the unification of the Soviet Union) in the Baltic states as well as in Moscow or Leningrad is caused by this kind of migrants.

The uneven distribution of the migrant population in Estonia is another question. Migration statistics do not register the place of birth. However, some picture of the structure of the migrant population could be obtained indirectly by using national origin (Figure 2). They are mainly concentrated in cities (north-eastern Estonia, Tallinn) and also in the military bases (e.g. Paldiski). It could be stated that the enlargement of Estonia's migration hinterland had a very uneven intraregional effect. In some cities this led to a two-waved urbanization. Kümmel (1986) has demonstrated the destabilization of the Estonian settlement system and the inertia of the settlement hierarchy of colonial nature. The situation is especially complicated in north-eastern Estonia.

The enormous in-migration into Estonia has resulted in different demographic behavior in the population. Two behavior types have been established: one typical to the Estonians and one to the non-Estonians. Certainly, the differentation is not so much caused by national origin than by the time differences in proceeding through the demographic transition and the corresponding general cultural background. It must be underlined that the second generation of the migrant population managed to preserve the behavior model typical to their home region which had not been syn- 
Figure 3. Completed fertility rates of estonian birth cohorts $1910-1950$ as assessed in 1985 .

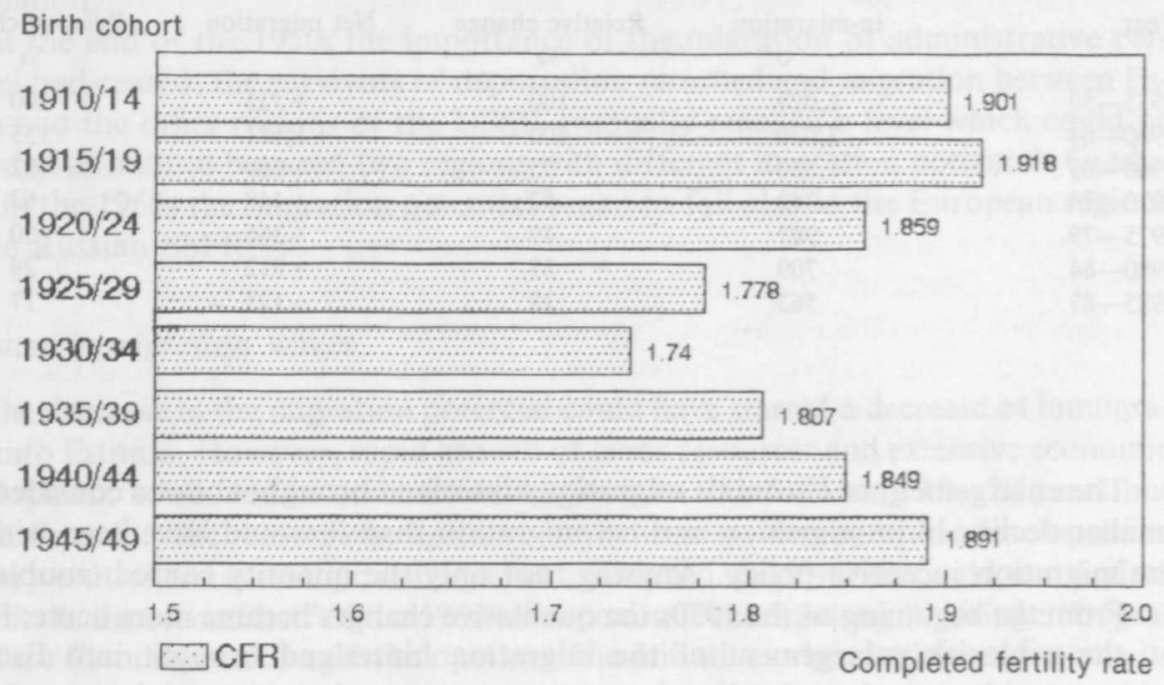

chronous with the Estonian one. The coexistence of the two behavior types is the basis for the demographic situation in Estonia of today and tomorrow.

\section{Fertility}

The difference between the two demographic behavior types is distinctly visible especially in the fertility process. Estonian fertility dynamics are in some extent unique in Europe, which demands more detailed treatment.

As an exception in the general European trend, Estonia ramained a country with low fertility during the post-war period. No baby boom broke out here, such as had been characteristic of the other countries with low fertility. In Estonia fertility remained below the replacement level, although the level itself slightly fell as infant mortality diminished. The Estonian population statistics up to 1959 are extremely insufficient and, particularly, no age structure is available. But the crude indices as well as the 1959 census data give no evidence of an increased fertility level during the $1940 \mathrm{~s}-1950 \mathrm{~s}$.

This statement is confirmed by the 1979 and 1985 census data on the completed fertility rate (Figure 3 ). The 1930-1934 birth cohort had their active reproductive age in the 1950s and the lowest completed fertility in all Estonian cohorts. In short, fertility in Estonia remained relatively low up to the mid 1960s.

The fertility trend changed in the second half of the $1960 \mathrm{~s}$. Measured by the period total fertility rate TFR, the fertility level rose by approximately 18 percent in $3-4$ years: from 1.9 in $1964 / 65$ to 2.2 in $1969 / 70$. The rise started in 1967 and the TFR reached its maximum in 1971 . That short-term jump turned out to be a long-term change. Comparing the 1968-1988 period and the preceeding 40-year-period of 1928 - 1968, one could see that the Estonians' fertility has been 15 percent higher in the later period. The qualitative aspect is far more important: having risen above the replacement level at the end of the $1960 \mathrm{~s}$, fertility has not fallen below that level since. 
After the sharp rise the fertility trend did not remain stable but had some fluctuations. During the 1970s the period indices declined; a new rise followed in the early 1980s. Now the fertility level measured by the period indices is approximately the same as at the beginning of the 1970s.

So far we have been studying the Estonians. They grant the continuity of the Estonian population. The second group of the population of Estonia had been formed after the Second World War by immigration. Another picture is revealed when observing the fertility dynamics of the migrant population (Figure 4). Their fertility had been rising at the end of the 1960 s, too, but it was relatively weak and shortterm. In the 1970 s the average fertility level of the migrant population was lower in comparison with the previous decade. In view of the general tendency, their fertility continued to decrease. In the 1980 s, the increase of the fertility of the migrants could be observed. The process began $1-1.5$ years later than that of the Estonians but was much stronger. This increase accelerated in 1987 and now its general level is rather close to the Estonians'. When the 1989 census data on the population age structure become available, an accurate comparison can be made.

In general, the fertility trend of the migrant population was rather close to the Slavic republics (departure regions of most immigrants), where a fertility increase has also been noticed at the beginning of the 1980s. The fertility trend of the Estonians once more happened to be different, but this time it resulted in the convergence of the fertility levels.

The rise in the period indicators of fertility has obviously to a certain extent been caused by the structural shift in the timing of births. As the mean age of the mother for a live birth got younger, the period indicators went through a cumulative effect. Figure 5 demonstrates that within 25 years, from the 1930 s up to the end of the 1950 s, rejuvenation of the fertility curve had been weaker than in the following ten-year period. As earlier, the 25-29-year-old age group had their maximum fertility at the end of the 1950s. Nevertheless, fertility had fallen in all age groups above 30 and

Figure 4. Dynamics of total fertility rate, 1958-1987.

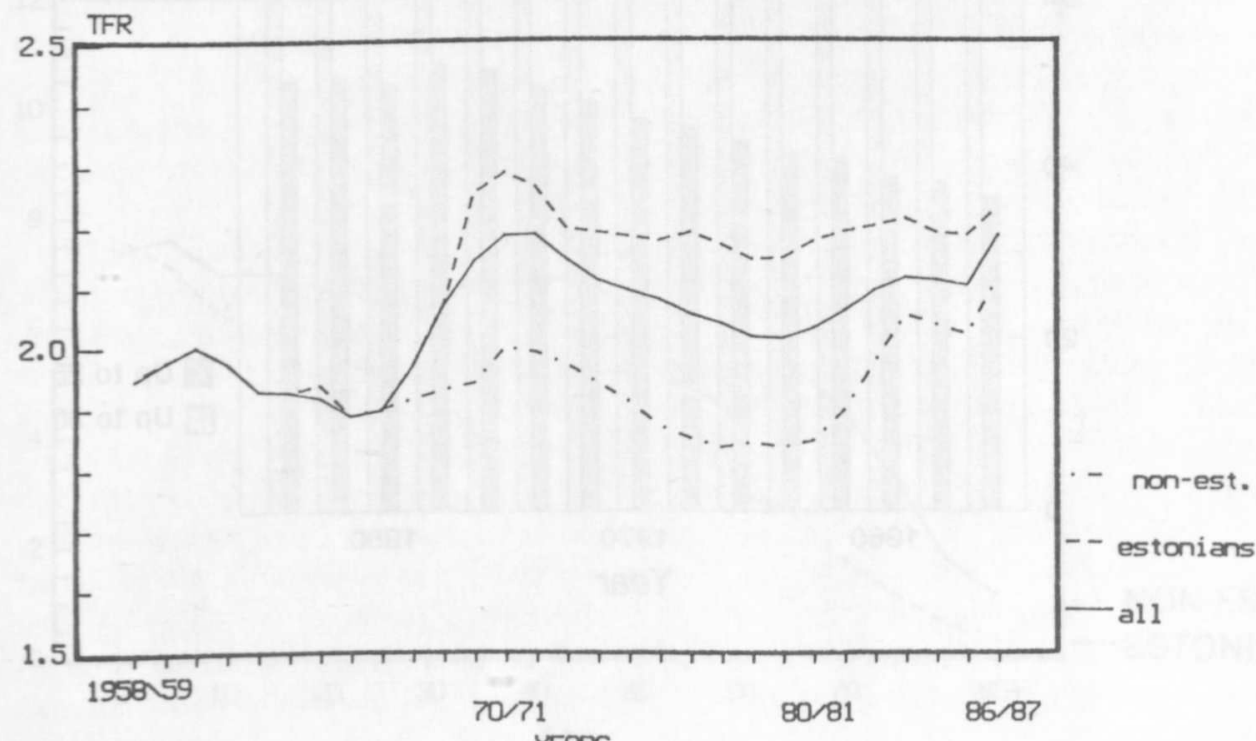


Figure 5. Comparison of age-specific fertility rates.

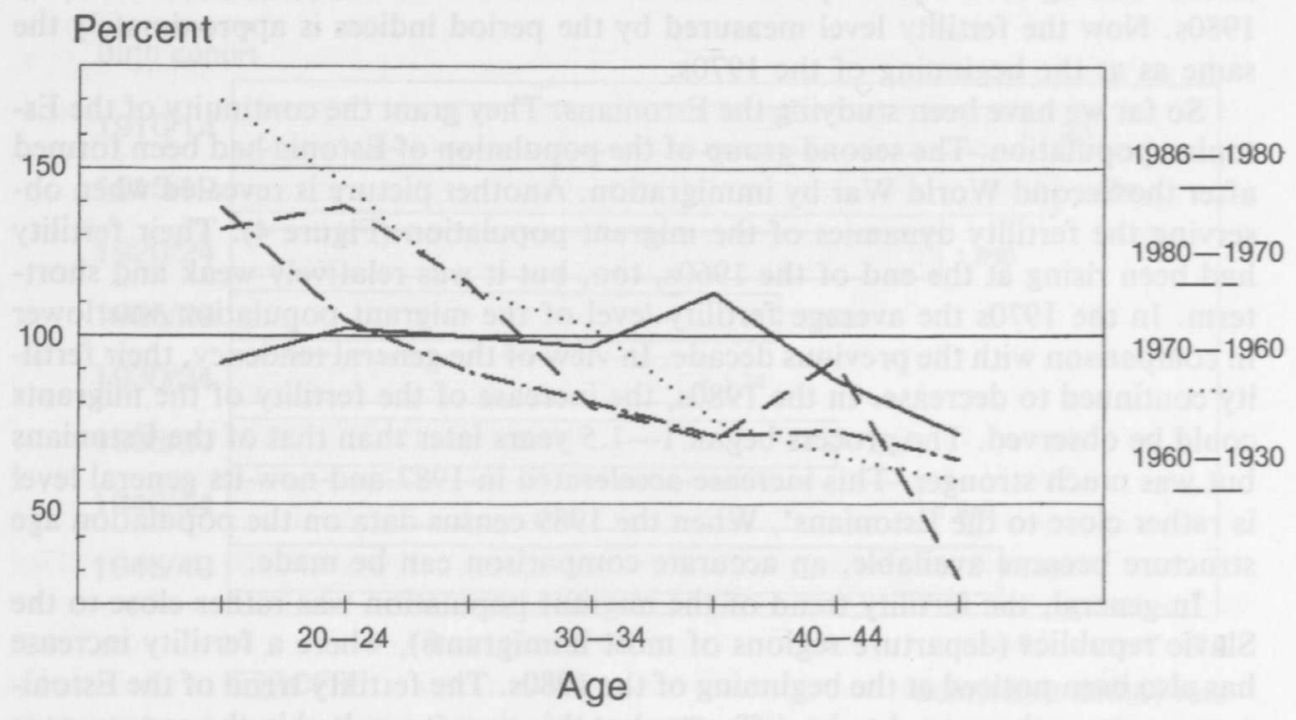

Figure 6. Share of children born to women up to age 25 and 30.

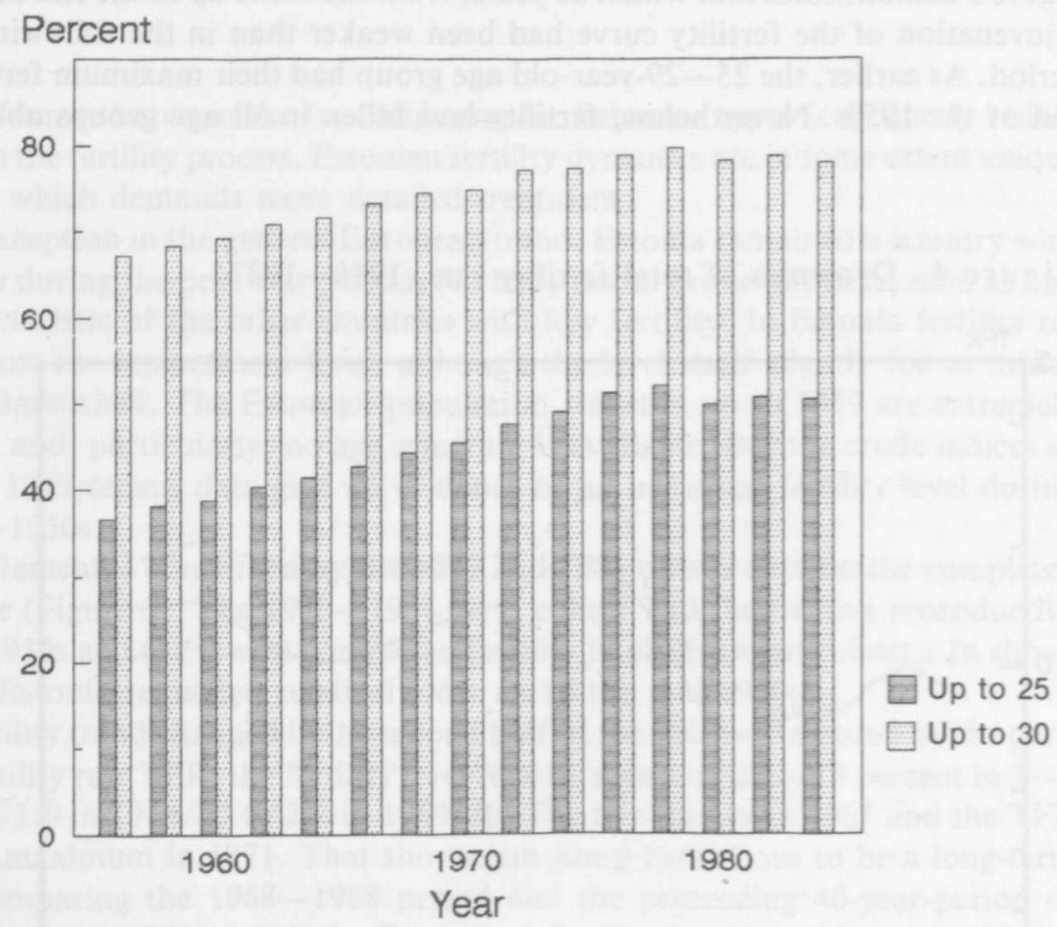


had risen remarkably at the age of $20-24$. There was a rapid movement towards rejuvenation during the following decades. At the beginning the fertility rise was common to all age groups up to the age of 35 . The comparison of the late $1950 \mathrm{~s}$ and the 1980 s specifies that the present generally higher fertility is caused by the higher fertility of the 15-24-year-olds.

Fertility rejuvenation is a parallel process to the disappearance of the European marriage pattern and the continuous rise of the illegitimate birth rate.

Despite the fertility rejuvenation causing the cumulative growth of all period indicators, it does not seem to be the real cause for the fertility rise. It is rather simple to demonstrate that fertility rejuvenated before the start of the rise and also in the 1970 s, when fertility had a falling trend, as well as during the period of growth (Figure 6). Fertility rejuvenation remained a rather linear process during the sharp changes in the fertility trend. Although fertility rejuvenation seems to have slowed down or even ceased in the $1980 \mathrm{~s}$, it does not indicate a fall in fertility but quite a contrary trend in Estonia.

The high fertility level of the Estonians is especially remarkable because it takes place under the principally similar social changes as in the rest of Europe. The emancipation of women is in process in Estonia as everywhere else. Women's employment here is one of the highest in the world: according to the 1979 census data a woman was employed for 37.4 years (gross working period) out of her 74.2-yearlong life span (Puur 1987). The frequency of first marriages is slowing down and cohabitation is gaining importance, which is characteristic of the Estonians, in particular. The legitimacy of the first births would help us to get a picture of the spread of this phenomenon, which has not yet been studied.

Figure 7. Comparison of estonians and non-estonians age structure, 1979.

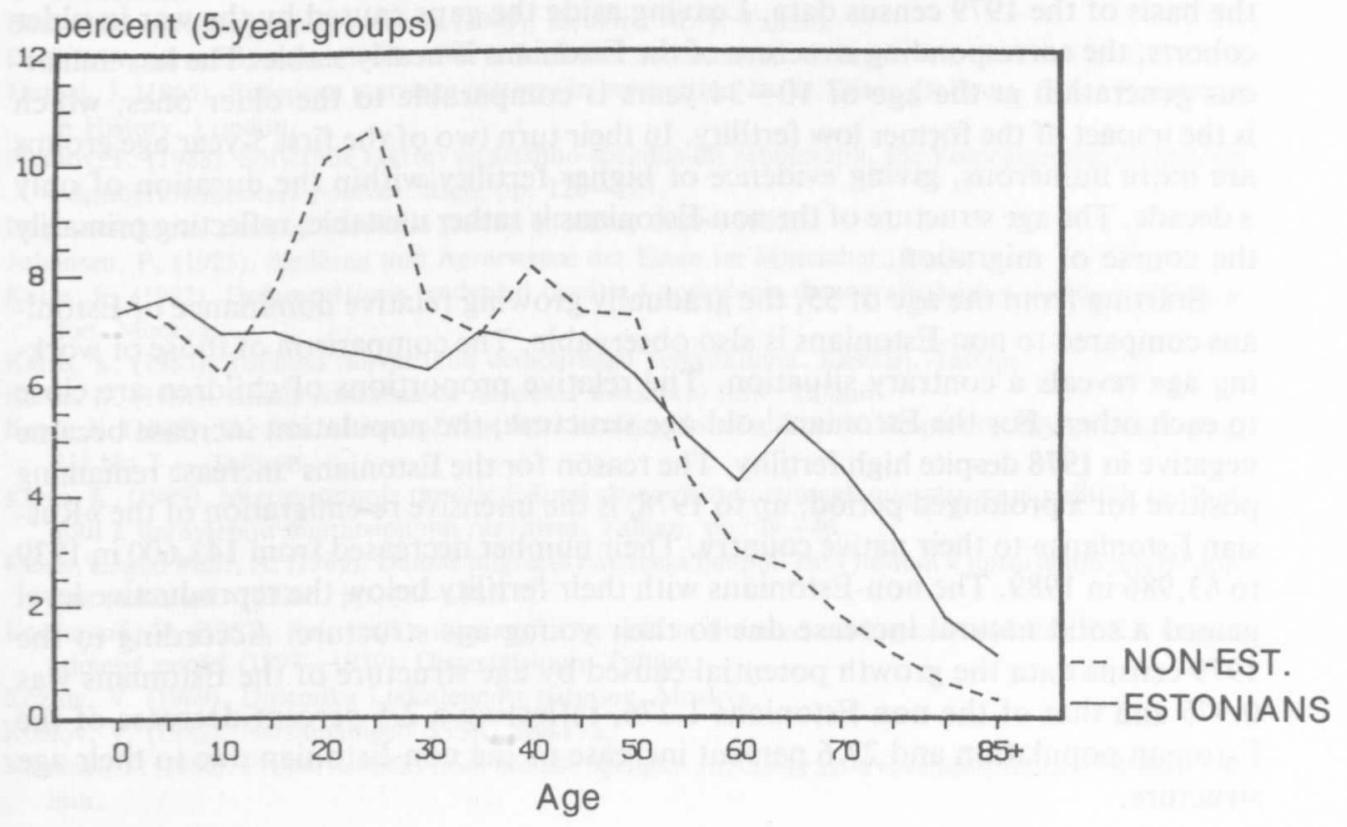


The Estonians had 36 percent of their first child illegitimately in 1987.38 percent had their first child during the first 7 months of marriage. Hence, 74 percent of the first children were fecundated out of wedlock. The corresponding data for the nonEstonians are 17 percent, 28 percent and 45 percent. One difference compared to the European countries should be mentioned: in Estonia fertility is primarily regulated by the traditional methods and abortions because of the lack of modern contraceptives in the USSR. The total abortion rate in Estonia was 3.22 in 1985 and exceeded considerably the TFR (Avdeev 1988, 23).

\section{Mortality}

Mortality bears the typical mark of Eastern Europe. By the end of the 1960s the mean length of life at birth rose to 70 years (70.4 in 1969/70), mainly because of decreasing infant mortality. Later the rise ceased and a certain decrease was observed. The length of life in 1986/87 was practically at the same level as 20 years ago. Although male mortality has been slightly decreasing, the sex differences in the length of life are continuously high: 66.4 years for men and 75.1 years for women (1986/87). The Estonian population is characterized by the cause-specific mortality structure of the developed countries but the average life span in shorter by the majority of causes of death. Especially heart diseases cause comparatively early deaths (Hindov 1988). The only published nationality-specific life tables (Estonians, non-Estonians) date back to the 1979 census data on the Tallinn population. The length of life of Estonians (71.35) slightly exceeded that of non-Estonians (70.26). However, the mortality curves were rather similar (Katus 1983, 33-37). Only the lower mortality among the Estonians over 70 years of age made a notable difference. It is assumed that a little more detailed research would reflect the differences between the native and the migrant population of Estonia.

In the formation of the present demographic situation and the next 20 years the most prominent factor among the differences in the demographic behavior will be the difference between the age-specific structures of the native and the migrant population. Figure 7 provides a comparison of the age-nationality-specific structures on the basis of the 1979 census data. Leaving aside the gaps caused by the war in older cohorts, the corresponding structure of the Estonians is nearly stable. The less numerous generation at the age of 10-34 years is comparable to the older ones, which is the impact of the former low fertility. In their turn two of the first 5-year age groups are more numerous, giving evidence of higher fertility within the duration of only a decade. The age structure of the non-Estonians is rather unstable, reflecting primarily the course of migration.

Starting from the age of 55, the gradually growing relative dominance of Estonians compared to non-Estonians is also observable. The comparison of those of working age reveals a contrary situation. The relative proportions of children are close to each other. For the Estonians' old age structure, the population increase became negative in 1978 despite high fertility. The reason for the Estonians' increase remaining positive for a prolonged period, up to 1978 , is the intensive re-emigration of the "Russian Estonians» to their native country. Their number decreased from 143,600 in 1939 to 63,986 in 1989 . The non-Estonians with their fertility below the reproductive level gained a solid natural increase due to their young age structure. According to the 1979 census data the growth potential caused by age structure of the Estonians was 0.975 and that of the non-Estonians 1.276 , reflecting a 2.5 percent decrease of the Estonian population and 27.6 percent increase of the non-Estonian due to their age structure. 


\section{Instead of a conclusion}

The demographic prognosis of the Estonian migration hinterland shows the ceasing of the migration potential and the beginning of a population decrease at the end of the first decade of the 21 st century. If the migration hinterland does not grow further, Estonian net migration will become negative within $8-12$ years.

Estonian internal demographic development will be continuously determined by two types of demographic behavior and age-structural differentation, i.e. that of the native and that of the migrant population. The first enlarged cohorts of the Estonians, due to the fertility increase at the end of the $1960 \mathrm{~s}$, have now reached fertile age. The number of births will grow, even if fertility continues to decrease. The negative age-structural growth of Estonians is over. The non-Estonian population will be characterized by rapid aging, the rate of which will greatly depend on fertility trends. During the next two decades the growth of the non-Estonians will be noticeable, as before. However, at the end of the first decade of the 21st century it will start to decrease, first in relative, then in absolute terms.

There is no scientific basis for making a mortality prognosis. But the probable decrease of mortality is going to affect demographic development, population aging in particular.

The demographic development in Estonia and in its neighboring regions started to differ more than 250 years ago and will affect the population situation in Estonia even in the next century.

\section{References}

Avdeev, A. (1988). Službi, svazannie s planirovaniem semi. In: Regionalnie i medikodemografitsheskie osobennosti planirovania semi. Moskva, pp. 20-33.

The Biography of a People (1974). Past and Future Population Changes in Sweden. Gothenburg, Lund, Stockholm.

Eesti NSV rahvamajanduse näitarve (1940). Kuukiri, No 1. Tallinn.

Eesti NSV rahvamajandus (1967-1987). Statistika aastaraamat. Tallinn.

Hajnal, J. (1965). European marriage patterns in perspective. In: D. Glass, D. Evers. (Eds.) Population in History. London.

Hindov, E. (1988). Sotsialnie faktori serdetshno-sosudistihh zabolevanii. In: Vosproizvodstvo naselenia i demografitsheskaja politika. Riga, pp. 120-127.

Itogi vsesojuznoi perepisi naselenia (1989). Moskva, 1989-1990.

Johansen, P. (1925). Siedlung und Agrarwesen der Esten im Mittelalter. Tartu.

Katus, K. (1982). Dolgosrotshnie tendentsii razvitia i upravlenia demografitsheskoi sistemoj. Dissertation. Moskva.

Katus, K. (1983). Tallinna rahvastikuu demoarengu perspektiivid. Käsikiri, Tallinn.

Katus, K. (1987). Anaľz rozdaemosti naselenia Estonskoi SSR. Tallinn.

Katus, K. (1988). The Distinctions of Post-War Fertility Trend in Estonia. Report on IIASA Conference. RU No 7 - Tallinn.

Katus, K. (1989). Migratsionnoje razvitie Estonii skvoz prizmu strategii migratsionnoi politiki. In: Podhodi $\mathrm{k}$ upravleniju migratsionnim razvitiem. Tallinn, pp. 29-46.

Katus, K. and Puur, A. (1989). Dannie migratsii naselenia Estonii. In: Podhodi k upravleniju migratsionnim razvitiem. Tallinn, pp. 164-187.

Kaufmann, V. (1967). Rahvastiku dünaamika ja seda mõjutanud seaduspärasused Eestis XX sajandi esimesel poolel (1897-1959). Dissertatsioon. Tallinn.

Kozlov, V. (1969). Dinamika i tshislennost narodov. Moskva.

Kozlov, V. (1982). Natsionalnosti SSSR. Moskva.

Kümmel, T. (1986). Proportsioonid Eesti linnade agengus. In: Geograafia rakendusprobleeme Eestis. Tallinn. 
Laasi, E. (1988). Kuritegu inimsuse vastu. Kodumaa, No 46 (1568). Tallinn.

Laas, K. (1978). Rahvastikuprotsessidest Eestis. Tallinn.

Ligi, H. (1974). Dinamika krestjanskogo naselenia v Estonii v 1712-1782. In: Tezisi dokladov na pervom vsesojuznom seminare po istoritsheskoi demografii. Tallinn.

Maamägi, V. (1976). Estonskie poselentsi v SSSR. Tallinn.

Moora, H. (1961). Eesti NSV ajalugu, kd.1, Tallinn.

Nigol, A. (1918). Eesti asundused ja asupaigad Wenemaal. Tartu.

Noukogude Eesti (1978). Entsüklopeediline teatmeteos. Tallinn.

Palli, H. (1973). Ajaloolise demograafia probleeme Eestis. Tallinn.

Palli, H. (1977). Vosproizvodstvo naselenia Estonii v XVII-XIX vv. In: Bratshnost, roždaemost, smertnost v Rossii i v SSSR. Moskva, pp. 214-229.

Palli, H. (1980). Estestvennoe dviženie selskogo naselenia Estonii 1650-1799. Tallinn.

Palli, H. (1988). Otepää rahvastik aastail 1716-1799. Tallinn.

Parming, T. (1972). Population changes in Estonia 1935-1970. Population Studies 26 (1): 53-78.

Pavlik, Z. and Hampl, M. (1975). Differentiation of demographic systems according to development and rank with special regard to the third world. The Hague.

Pullat, R. (1981). Peterburi eestlased. Tallinn.

Puur, A. (1987). Analiz zanjatosti naselenia Estonskoi SSR. Tallinn.

Rahva demograafiline koosseis ja korteriolud Eestis, 1924. Vihk I. Tallinn.

Rahvastikuprobleeme Eestis (1937). 1.III 1934 rahvaloenduse andmed. Vihk IV. Tallinn.

Rahvastik ja tervishoid Eestis (1930). Eesti Demograafia. Vihk IV. Tallinn.

Rashin, A. (1956). Naselenia Rossii za sto let (1811-1913). Moskva.

Strömmer, A. (1969). The demographic transition in Finland. Yearbook of Population Research in Finland. 11: 101-116.

Taagepera, R. (1989). Miks ja kuidas Eestist ära. Vikerkaar, No 1, 1k. 60-65.

Tarvel, E. (1970). Eesti NSV. Feodalismiajastu. In: ENE, 2 kd. Tallinn.

Vahtre, S. (1973). Eestimaa talurahvas hingeloenduste andmeil (1782-1858). Tallinn.

Vishnevski, A. and Volkov, A. (Eds.) (1983). Vosproizvodstvo naselenia SSSR. Moskva.

Vōime L. (1975). Estonskie poselenia na Tshernomorskom poberežje Kaykaza. Dissertation. Moskva.

Zelinski W. (1971). The Hypothesis of the Mobility Transition 11 Geographical Review, 61 (2): 219-249.

Zvidrinš, P. (1983). Demographic transition in Latvia. In: Khalatbari (Ed) Demographic Transition. Berlin. 